\title{
Dialog podle Viléma Flussera: prostřednictvím Martina Bubera k novým technologiím
}

\section{Dialogue according to Vilém Flusser: from Martin Buber to new technologies}

Klára Židková

\begin{abstract}
Abstrakt
Tento článek se zabývá filozofií dialogu Martina Bubera a filozofickými motivy, které z Buberovy koncepce dialogu převzal esejista a teoretik komunikace Vilém Flusser. Stat' představuje Flusserovu vlastní koncepci dialogu, do níž se Buberovy myšlenky promítly. Snahou je poukázat, $v$ čem se Flusserovo pojetí od Buberova odlišuje. Jde zejména o Flusserův odklon od chápání autentického dialogu jako rozmluvy dvou osob k chápání dialogu v podmínkách masové komunikace prostřednictvím médií a nových technologií. Diskutována bude i otázka, zda a jakým způsobem se vztahuje Flusserova komunikační teorie k židovské filozofii obecně.
\end{abstract}

\section{Klíčová slova}

Vilém Flusser, Martin Buber, dialog, diskurs, filozofie dialogu, komunikační teorie, Já a Ty, Já a Ono, projekce, média, židovství

\begin{abstract}
This article deals with Martin Buber's philosophy of dialogue and with the philosophical motifs that the essayist and theorist of communication Vilém Flusser adopted from Buber's concept of dialogue. The text presents various aspects of Flusser's conception of dialogue into which Buber's thoughts projected. The author attempts to show how Flusser's approach differs from Buber's, in particular how Flusser deflected from the understanding of the authentic dialogue as a dialogue of two particular people to the concept of dialogue in the framework of mass-communication through media and new technologies. The question
\end{abstract}


of whether and how Flusser's communication theory relates to Jewish philosophy in general is discussed as well.

\section{Keywords}

Vilém Flusser, Martin Buber, dialogue, discourse, the philosophy of dialogue, communication theory, I and Thou, I and It, projection, media, Jewishness

„Respondeo, ergo sum.“ ${ }^{1}$

Za zásadní inspirační základ pro celou komunikační teorii pražského rodáka Viléma Flussera můžeme považovat filozofii dialogu, kterou v první polovině 20. století rozvinul židovský existenciální filozof, mystik a překladatel hebrejské bible do němčiny Martin Buber. Následující stat se zabývá momenty, ve kterých se Buberova vlastní filozofie otiskla do té Flusserovy. Vedle toho se však text také snaží poukázat, jak Flusser Buberovu koncepci vychýlil mimo její původní rámec. Filozofický projekt s jasným religiózním podtextem totiž Flusser použil v „zesvětštělé“ verzi pro své úvahy o komunikaci v posthistorické době, ale i v dalších rovinách. Nicméně zde zůstává otázka, zda i Flusserova komunikační teorie není jen specifickou adaptací židovské filozofie a židovského pojetí víry v širší rovině, z nichž silně čerpá také Buberova filozofie dialogu, ale i další židovští existenciálně orientovaní filozofové. Vedle principu dialogického života lze totiž jisté paralely vysledovat také mezi vztahem starozákonní víry k zobrazování a zobrazovacímu procesu a mezi Flusserovou koncepcí technických obrazů. ${ }^{2}$

Flusser Bubera explicitně zmiňuje na mnoha místech svých textů v souvislosti se svými vlastními popisy dialogického života. Flusser však opět neuvádí

1 Gerhard Wehr, Buber, přel. Mária Schwingerová, Olomouc: Votobia 1995, s. 84.

2 Právě vlivu filozofie Martina Bubera na Flusserovo vlastní myšlení se některé statě již detailněji věnují. Např́́klad viz Andreas Ströhl, Vilém Flusser (1920-1991): Phänomenologie der Kommunikation, Köln: Böhlau Verlag 2013, publikace vyšla v českém překladu v roce 2016 jako Andreas Ströhl, Vilém Flusser (1920-1991): Fenomenologie komunikace, přel. Zuzana Jürgens - Jana Vymazalová, Praha: Argo 2016, nebo viz Oliver Bidlo, Martin Buber: Ein vergessener Klassiker der Kommunikationswissenschaft? Dialogphilosophie in kommunikationswissenschaftlicher Perspektive, Marburg: Tectum Verlag 2006. Oba texty spíše zdůrazňují Flusserův odklon od Buberovy religiozity, zatímco tato stat chce spíše upozornit na možnost, že jistý vliv judaismu je ve Flusserově komunikační teorii stále imanentně přítomen. 
konkrétní Buberovy spisy nebo pasáže textů, z nichž inspiraci načerpal. Nemáme tedy přesnou představu, s kterými Buberovými texty byl obeznámen a s kterými nikoliv. Víme však, že se Flusser s Buberovou filozofií setkal již v mládí v rodné Praze. V rozhovoru s Patrickem Tschudinem z 30. září 1991 Flusser vzpomíná na Buberovu pražskou přednášku, které se jako mladý zúčastnil. ${ }^{3} \mathrm{~V}$ odpovědi na otázku, odkud čerpá důkazy pro svou tezi, že "Já“ je pouhou funkcí jiného či druhého a naopak, Flusser odpovídá:

To je dobrá otázka. Skutečně nejde o moji tezi, chci vám to ukázat na svém vlastním životopise. Byl jsem sedmnáctiletý, možná osmnáctiletý kluk, když Buber přijel do Prahy. Zanechalo to ve mně neuvěřitelný dojem. Už ty dlouhé černé vousy, pevné vzezření a ten pohled! To byl pohled proroka! Nemluvil o dialogickém životě, ale o předsudku vůči Bohu. Mluvil úžasně. $V$ této jeho přednášce mi bylo jasné, co Buber pojmy „Já a Ty“ myslí, co chápe pod pojmem dialogický život. ${ }^{4}$

Dochoval se přepis Buberovy přednášky z 13. ledna 1937 s názvem Předsudky mládeže. Proslov $k$ židovské mládeži ze dne 13. ledna 1937.5 Tematicky i časově tato Buberova přednáška odpovídá té, na kterou vzpomíná Flusser. ${ }^{6}$ Přednáška byla určena židovské mládeži. V obecnějším smyslu však apelovala v ovzduší rozmáhajících se totalitních hnutí na snahu neupadat do stádního stylu uvažování, na obnovu angažovaného postoje každého jedince a na obnovu pravého společenství, které je založené na bezprostředním vztahu mezi člověkem a člověkem. V konkrétním přístupu k druhým se totiž podle $\mathrm{Bu}$ bera rozkládá úrodná půda pravého společenství. ${ }^{7}$ Buberův důraz na vztah člověka vưči člověku (Já vůči Ty) je patrný i v této přednášce.

3 Viz Vilém Flusser, Klaus Sander (ed.). Zwiegespräche: Interviews 1967-1991, Göttingen: European Photography 1996.

4 Tamtéž, s. 203. Srov.: „Das ist eine gute Frage. Es ist ja nicht meine These, und das will ich Ihnen an meiner Biographie zeigen. Ich war ein Bub von vielleicht 17, 18 Jahren, da kam der Buber nach Prag. Das hat bei mir einen unglaublichen Eindruck hinterlassen. Schon dieser große schwarze Bart und diese starke Gestalt und dieser Blick! Das war ein Blick eines Sehers! Und er sprach nicht über das dialogische Leben sondern über das Vorurteil gegen Gott. Er hat das fabelhaft gesagt. In diesem seinem Vortrag wurde mir deutlich, was Buber mit dem „Ich und Du' meint, was er mit dem dialogischen Leben meint.“

5 Viz Martin Buber, Předsudky mládeže: Proslov k židovské mládeži ze dne 13. ledna 1937, Praha: Sionistický obvodový výbor pro Čechy 1937.

$6 \quad$ Vilém Flusser se narodil v Praze v roce 1920.

7 M. Buber, Př́dsudky mládeže..., s. 8. 
Sám Buber v doslovu ke svému textu Zwiesprache $e^{8}$ zmiňuje, že principem dialogu, dialogického života a filozofií dialogu se zabývali již mnozí autoři před ním. K průkopníkům dialogického principu patřili Johann Georg Hamann, Wilhelm von Humboldt, Johann Gottlieb Fichte či Ludwig Feuerbach. Buberova koncepce vztahu mezi Já a Ty je v př́́padě projektu filozofie dialogu považována za konstitutivní. Martin Buber rozpracoval základy svého dialogického principu ve dvacátých letech 20. století. V roce 1923 byl vydán Buberův klíčový spis Já a ty, ${ }^{9}$ jehož myšlenky Buber v dalších desetiletích v podstatě pouze rozpracovával v dalších textech. Buber zmiňuje, že koncept dialogického principu rozvinul v souvislosti s potřebou dialogu, kterou pocitoval v mezidobí mezi světovými válkami. ${ }^{10} \mathrm{Na}$ dobovou ukotvenost Buberovy filozofie dialogu upozorňuje také Gerhard Wehr.

Jednostranný individualismus a radikální kolektivismus zanechaly př́liš hluboké rány. Člověk, jenž v pluralistické společnosti osaměl, se ptá po možnosti postavit most od ,já“ k „ty“; ptá se po jejich spojení, které lze uskutečnit v rozhovoru a setkání. ${ }^{11}$

V textu Já a ty Buber tvrdí, že existují dva typy „relací“, jejichž prostřednictvím můžeme vstupovat do kontaktu s okolním světem. Jeden vztah se může proměňovat $\mathrm{v}$ druhý na základě našeho postoje a také $\mathrm{k}$ tomu nevyhnutelně dochází. Jedná se o relace "Já-Ono“ a "Já-Ty“. Ve vztahu "Já-Ono“ je já individualitou, která si uvědomuje sama sebe jakožto subjekt, který ke světu přistupuje předmětně, jakožto k objektům. Svět slova „Ono“ je souvislý v prostoru a čase. Člověk je pouze předmětem mezi ostatními předměty. ${ }^{12}$ Jde o poznávací kategorii. V tomto vztahu, kdy já přistupuje k druhým jakožto k předmětům, nelze podle Bubera dosáhnout autenticity a podstaty bytí. Předmětná řeč totiž zachycuje pouze určitý úsek skutečného života. ${ }^{13}$ Ten se odhaluje pouze v dialogu, ve vztahu "Já-Ty“. V tomto případě, není já subjek-

8 Viz Martin Buber, Zwiesprache: Traktat vom dialogischen Leben, in Martin Buber, Das dialogische Prinzip, Gerlingen: Schneider 1997.

9 Viz Martin Buber, Já a ty, přel. Jiří Navrátil, Praha: Mladá fronta 1969. První verze textu Já a ty vznikla už v roce 1919, definitivní podobu dostal text v roce 1922 a v roce 1923 byl poprvé vydán.

10 Viz M. Buber, Zwiesprache..., s. 145.

11 G. Wehr, Buber..., s. 6.

12 Viz M. Buber, Já a ty..., s. 55.

13 Viz tamtéź, s. 18. 
tem, ale konkrétní osobou, která si uvědomuje svou subjektivitu skrze svůj vztah k druhému. ${ }^{14}$ Jedná se o vztahovou kategorii, zaměřenou na komunikaci. Buber pro popis vztahu mezi „Já“ a „Ty“ často užívá mystických termínů. Jde o skutečné bezprostřední setkání. A teprve skrze toto setkání s druhým, dosahuje "Já" své skutečnosti.

Stávám se vskutku sebou jen díky svému vztahu k „Ty“; stávaje se sebou říkám „ty“. Všechen skutečný život je setkáním. [...] Vztah k „Ty“ je bezprostřední. Mezi "Já“ a „Ty“ není žádná soustava pojmů, žádné předchozí vědění a žádná představivost [...]. Jenom tam, kde se všechny prostředky hroutí, dochází k setkání. ${ }^{15}$

Setkáním s „Ty“ v dialogu má Buber na mysli, skutečné, konkrétní, bezprostřední setkání s druhým člověkem tváří v tvář. Toto setkání má také neoddělitelný religiózní přesah. Jedině prostřednictvím setkání s druhým člověkem se realizuje vztah a oslovování a dialog s věčným Ty. Lidský život je podle Bubera utvářen centrálním „Ty“, které bylo přijato v živé přítomnosti. ${ }^{16}$

Nahoře a dole je vzájemně propojeno. Kdo chce mluvit $\mathrm{s}$ lidmi, aniž by u toho současně mluvil s Bohem, nikdy nebude mluvit úplně; ale kdo chce mluvit s Bohem, aniž by u toho mluvil s lidmi, toho slovo povede k bláznovství. [...] Vypráví se, že se jednou jeden bohabojný muž vydal z řišse stvoření do velké prázdnoty. Tam putoval, až přišel k bráně Tajemství. Zaklepal. Zevnitř se ozvalo: „Copak zde pohledáváśs?“ „Hlásal jsem,“ odpověděl, „uším smrtelníků o Tvé slávě, ale byli vůči mým slovům hluší. A proto přicházím k Tobě, abys mě Ty sám vyslyšel a odpověděl mi.“ „Obrat’ se zpátky,“ ozvalo se zevnitř, „zde není žádné ucho, které by tě vyslechlo. Do hluchoty smrtelníků jsem zapustil své naslouchání."17

14 Viz tamtéž, s. 55.

15 Tamtéż, s. 13-14.

16 Tamtéž, s. 42.

17 M. Buber, Zwiesprache..., s. 160 a 161. Srov.: „Oben und unten sind einander gebunden. Wer mit den Menschen reden will, ohne mit Gott zu reden, dessen Wort vollendet sich nicht; aber wer mit Gott reden will, ohne mit den Menschen zu reden, dessen Wort geht in die Irre. [...] Es wird erzählt, ein gottbegeisteter Mann sei einst aus den Bereichen der Geschöpflichkeit in die große Leere gegangen. Da wanderte er, bis er an die Pforte des Geheimnisses kam. Er pochte. Von drinnen rief es ihn an: ,Was willst du hier?" „Ich habe, sagte er, ,den Ohren der Sterblichen dein Lob verkündet, aber sie waren mir taub. So komme ich zu dir, daß du selber mich vernehmest und mir erwiderst. ',Kehr um, ' rief es von drinnen, ,hier ist dir kein Ohr. In die Taubheit der Sterblichen habe ich mein Hören versenkt."“ 
Dialog s Bohem prostřednictvím druhých, to znamená skrze reálný dia$\log$ a vzájemnost, tvoří podle Bubera esenci bytí. ${ }^{18}$ Náboženskou zkušenost nelze podle něj nahradit kontemplativním ponořením se do vlastního nitra. Podle Wehra je pro Buberovu koncepci dialogu také velmi důležitá kategorie „mezi“. Je to skutečné místo a nositel všeho, co se odehrává mezi lidmi. "Já“ i „Ty“ jsou ve skutečnosti aspekty určitého silového pole, konkrétního intersubjektivního vztahu, který jediný je skutečný. Sféra „mezi“ neleží vně subjektivního, ani uvnitř objektivního, ale právě vytváří onu pulsující hranici, na níž se Já a Ty setkává. ${ }^{19}$

Buberovo pojetí dialogu (stejně jako Flusserovo) nepopisuje, co má být obsahem autentického dialogu, ale popisuje jej jako samotný akt komunikace či řečový proces, a to i ve vztahu k božskému „Ty“, o němž nelze říci nic konkrétního, nelze jej poznat, pouze jej oslovovat.

To, před čím žijeme, to, v čem, z čeho a k čemu žijeme - tajemství - zůstalo, čím bylo. Zpř́itomnilo se nám a zjevilo se nám ve své přítomnosti jako spása; „poznali“ jsme je, ale nemáme o něm žádného poznání, které by činilo jeho tajemnost menší - mírnější. Přriblí̌̌ili jsme se k Bohu, ale nejsme o nic blíže rozluštění hádanky bytí, sejmutí závoje z jeho tváře. Pocítili jsme vykoupení, ale nenašli jsme žádné „rozhřešení“. ${ }^{20}$

Vedle západních filozofických vzorů je zásadním Buberovým inspiračním zdrojem židovská bible a židovství obecně. Podle Wehra se do koncepce dialogu promítly také Buberovy vlastní niterné prožitky. Židovská bible podle Wehra pro Bubera představuje velkolepý dokument vzájemného vztahu mezi člověkem a Bohem. Minulé a současné dějiny jsou vyloženy jako jedinečný rozhovor, což platí, jak pro jednotlivce, tak pro kmeny, národy i lidstvo jako celek. $^{21}$

Motiv setkání se sakrálním prostřednictvím kontaktu s profánním je př́íznačný pro celou židovskou víru obecně např́íč jejími různými směry. Ještě více umocněna je v chasidském hnutí, v jehož teorii a praxi se Buber sám angažoval. A ačkoliv nelze podle Wehra označit Bubera přímo za chasida, zasahuje i tak jeho chasidismem ovlivněný život do jeho dialogické filozofie,

18 Viz Martin Buber, Temnota boží, přel. Tomáš Jeníček, Praha: Vyšehrad 2002.

19 Viz G. Wehr, Buber..., s. 85-86.

20 Tamtéž, s. 89.

21 Viz tamtéž., s. 75 a 76. 
biblické exegeze a jeho ozvuky lze najít i v Buberově německém překladu hebrejské bible. ${ }^{22}$

Vedle oficiální židovské ortodoxie se v průběhu staletí paralelně rozvíjela i více ezoterní forma židovské religiozity. Do této sféry spadá právě chasidismus, jehož kořeny vzniku se datují přibližně okolo roku $1700 \mathrm{v}$ oblasti východních Židů. Středobodem nebyl důsledný intelektuální výklad Tóry, jde o jeden z mystických proudů v židovství, který klade důraz na prožitek Boha prostřednictvím života ve společenství. Veškerá bohoslužba je jen přípravou ke kontaktu s Bohem přímo ve světě. ${ }^{23}$

Důležité ozvěny Buberovy filozofie dialogu nalezeme ve Flusserově myšlení hned v několika rovinách. Flusser se v nich povětšinou posouvá za Buberův kontextuální rámec. Ve Flusserově přístupu také nemůžeme hledat tak zcela evidentní inspiraci židovskou religiozitou jako u Bubera. Přesto ji však, jak se ukáže posléze, nemůžeme ani v př́ípadě Viléma Flussera považovat za irelevantní inspirační zdroj, protože ačkoliv Vilém Flusser sám nebyl Židem praktikujícím víru, s židovskou religiozitou jako takovou se ve svých úvahách rovněž vyrovnával.

$\mathrm{V}$ první rovině můžeme najít Buberův vliv ve Flusserově představě angažovaného intelektuála a v jeho pojetí intelektuálního dialogu. Flusser své esejistické texty, které píše, nepovažuje za hotové tvary, ale za podloží, na jehož základě se dialog se čtenářem může odehrát. Silný dialogický rozměr nalezneme také v jeho rozličných spolupracích a rozsáhlé korespondenci s množstvím brazilských i evropských intelektuálů. Jasný dialogický podtext, tedy konkrétně představu dialogu, prostřednictvím kterého lze dospět ke vzniku nových myšlenek, lze najít i za pravidelnými diskusními setkáními brazilských intelektuálů, jež se odehrávala na terase domu Flusserových v São Paulu.

V obdobném kontextu popisuje Flusser ve stati „Ubytovat se v bezdomoví“ ze svého esejistického souboru Bezedno motiv spolupráce s druhými a odpovědnosti za druhého v souvislosti se zkušeností exulanta a migranta. Flusser popisuje rozdíl mezi situací domova, kdy je člověku zodpovědnost za bližní automaticky přisouzena narozením do určitých podmínek, a mezi situací, kdy člověk sám ze své vůle na sebe bere zodpovědnost za druhého.

Tajuplná pouta, která člověka vážou $\mathrm{k}$ lidem doma (tedy třeba láska a přátelství, ale i zášt a nenávist), emigranta drásají, nebot problematizují svobodu, které

Viz tamtéž, s. 48-51. 
strastiplně dosáhl. Jsou to totiž dialogické nitky odpovědnosti a ručení za druhého. Je snad svoboda migranta, tohoto „ducha“ vznášejícího se nad všemi místy, nezodpovědnou, solipsistickou svobodou? Získal snad svou svobodu na účet soužití s bližními? Nebo je osamělost bez odpovědnosti migrantovým osudem (jak to chápou romantičtí básníci)? [...] Do prvního domova jsem byl vržen svým narozením, aniž jsem byl tázán, zda mi to vyhovuje. Pouta, která mě tam svázala s lidmi, mi byla většinou nasazena. Ve svobodě, jíž jsem dosáhl ted', jsem to já, kdo navazuje vazby s lidmi, a to ve spolupráci s nimi. Odpovědnost, kterou za lidi nesu, mi není uložena, ale převzal jsem ji sám. Nejsem jako ten, kdo zůstal s lidmi v tajemném svázání, ale ve svobodně zvoleném spojení. A toto spojení není o nic méně emocionální či sentimentální než ono svázání, je naopak právě tak silné, jenže svobodnější. To myslím, ukazuje jasně, co to znamená být svobodný. Ne přerušování vazeb k druhým, nýbrž vědomé navazování těchto vazeb ve spolupráci s nimi. ${ }^{24}$

Motiv dialogického života vedle Flusserova aktivního intelektuálního působení nalezneme i v jeho teoretických konceptech. Buberova distinkce mezi vztahy "Já-Ono“ a „Já-Ty“ nachází ozvuk ve Flusserově tezi, že čisté Já jakožto subjekt, který se vztahuje k okolnímu světu jakožto k předmětům, objektům, je konstrukt, jejž je potřeba překonat a opustit. Já není podle Flussera žádnou solidní entitou, ale spíše uzlovým silovým polem v síti intersubjektivních vztahů, které jediné jsou reálné a konkrétní. Zatímco Buber zdo̊razňuje, že neustálé přechody mezi předmětným („Já-Ono“) a vztahovým (Já-Ty“) přístupem jsou přirozené a nelze se jim vyhnout, Flusser spíše zdůrazňuje, že subjekt-objektové uvažování je třeba překonat ve prospěch toho relačního. ${ }^{25}$

V eseji „Von der Selbstlosigkeit“ Flusser popisuje, že společnost i jednotlivý člověk jsou pouze abstraktní extrapolace z konkrétních mezilidských vztahů, stejně jakožto subjekt a objekt jsou pouze abstrakce konkrétního intencionálně zaměřeného vztahového pole, nikoliv člověk a společnost jako celek, pouze intersubjektivní vztahy se svými napětími jsou konkrétní. ${ }^{26}$ Zde vidíme jistou souvislost s Buberovým oceněním kategorie „mezi“ jakožto skutečné kvality. Zatímco Buber klade důraz na dialogický vztah „Já-Ty“ jakožto cesty,

24 Vilém Flusser, Bezedno, přel. Božena Koseková - Josef Kosek, Praha: Hynek 1998, s. 192-193.

25 Andreas Ströhl ve své studii poznamenává, že Flusser akcentuje pouze dialogické vztahy a rovinu předmětnosti, Buberovu relaci "Já-Ono“ vypouští ze zřetele. Viz A. Ströhl, Vilém Flusser (1920-1921)..., s. 154. Ve skutečnosti však Flusser tuto relaci nevypouští, ale opakovaně se k ní kriticky vymezuje jako ke klamnému postoji.

26 Viz Vilém Flusser, Von der Selbstlosigkeit, s. 9. Kopie nevydaného rukopisu je dostupná ve Vilém Flusser Archiv při Universität der Künste Berlin (1142; 1-PHD2-35). 
jak dospět k autenticitě bytí jako konkrétní osoba, Flusser spíše zdůrazňuje fakticitu intersubjektivity jako cestu, jak prohlédnout klam, do nějž nás uvrhly západní tradice myšlení a západní věda.

V článku „Man as a subject or project“ Flusser tvrdí, že je potřeba proměnit náš postoj ke světu a nastolit tak zcela novou antropologii. Již od počátku dějin se lidé podle něj stavěli do kontradiktorického postoje vůči světu. Taková antropologie, postavená na kontradikci člověka a světa předkládá mylné problémy. Ve skutečnosti nejde o to, jak a zda je člověk jako subjekt schopen reflektovat svět, ale o to, že svět je v podstatě naší projekcí. A to v tom smyslu, že jsme to my sami, kdo promítá vlastní způsob myšlení do světa a potom je znovuobjevuje ve světě, jako bychom zapomněli, že jsme je předtím do světa sami promítli. Neboli - prŕrodní zákony nejsou objevy, extrakce přírody, ale projekce. ${ }^{27}$

Je tím řečeno velmi jednoduše, že nemůže existovat žádný objekt bez subjektu, který by jej pozoroval (žádná „věc o sobě,“) a že nemůže být žádný subjekt bez objektu, k němuž se jakožto subjekt vztahuje (žádné „čisté já“). Je tím míněno, že subjekt a objekt jsou abstraktní extrapolace z konkrétních vztahů. [...] Toto vše je velmi jednoduché, ale jde to velmi těžko uchopit, protože to je v protikladu k celé Západní tradici. ${ }^{28}$

Na úvahách o překonání předmětného př́ístupu ke světu pracoval Flusser v poslední etapě svého života, zejména v osmdesátých letech 20. století. Napsal na toto téma několik esejí (například již zmiňované „Von der Selbstlosigkeit“ nebo „Man as a subject or project“), téma také rozpracovával ve dvou knižních projektech „Vom Subjekt zum Projekt“ a „Menschwerdung“, oba však nestihl kvůli svému úmrtí dokončit. Oba texty pak vyšly posmrtně jako Vom Subjekt zum Projekt. Menschwerdung..$^{29}$ Zatímco Buberova dialogická filozofie vznikla na podloží otázky, jak založit autentické lidství v době společenské

27 Viz Vilém Flusser, Man as a subject or project, in Constructivism: Man versus Environment, Dordrecht: Stichting PRO 1989. Kopie textu je dostupná ve Vilém Flusser Archiv při Universität der Künste Berlin (822, M25-PRO3-01).

28 Tamtéž. Srov.: „It says quite simply that there can be no object without any subject to observe it (no ,thing in itself $)$ and there can be no subject without any object it is subject to (no ,pure subject'). It says that subject and object are abstract extrapolations from concrete relations. [...] All this is very simple, but it is difficult to grasp because it is contrary to Occidental tradition."

29 Viz Vilém Flusser, Vom Subjekt zum Projekt. Menschwerdung, Frankfurt am Main: Fischer Taschenbuch Verlag 1998. 
vyhrocenosti dvou světových válek, Flusser se ptá, jak pojmout lidství a vztah člověka ke svému okolí v situaci enormního technologického a vědeckého rozmachu. V textu „Man as a subject or project“ dokonce tvrdí, že počítače jsou technologie, díky nimž nám intencionální, relační povaha vlastního já, jež projektuje své vlastní koncepty do světa, může být zřejmější. Svět se nám po překonání subjekt-objektové dichotomie může otevřít jako všemožně se překrývající pole možností, jež jsou variabilně roztroušené a stávají se konkrétními na základě určitých projektů (intencionalit).

Není to náhoda, že nám počítačové obrazovky pomáhají uchopit tuto vizi: ony samy jsou produktem nového existenciálního postoje, který se objevuje. Počítače patří k nástrojům, jejichž prostřednictvím začínáme pokládat samy sebe za projekty. [...] Co nyní začínáme pocitovat, je to, že je zde kolem nás a v nás nespočetné množství virtualit, že zde v podstatě není žádný rozdíl mezi vně a uvnitř, a že tyto virtuality jsou pro nás možnosti, jak se stát konkrétními na základě specifických projektů. ${ }^{30}$

Flusser tvrdí, že tradiční dichotomie jako subjekt-objekt, duše-tělo, mysl-hmota jsou koncepty, které musíme opustit, a místo nich pracovat s dichotomií konkrétní-abstraktní, která jediná je adekvátní. Ve Flusserově pojetí je realita sítí realizovaných intersubjektivních vztahů a relací a uzlovým bodům v síti intencionalit odpovídá to, co zpravidla chápeme pod pojmem "Já“. Nová antropologie musí podle Flussera vidět člověka jako virtuálního konstruktéra sebe sama a svého světa. ${ }^{31}$ Řečeno Buberovými termíny pouze „my“ (vztahovost, intencionalita) je podle Flussera konkrétní, zatímco „já“ a „ty“ jsou pouze abstraktní deriváty tohoto vztahu. Autentická lidská existence podle Flussera znamená přijetí této skutečnosti. ${ }^{32}$ Překonání subjektové antropologie ve prospěch té projektové pro Flussera znamená otevřít se

30 V. Flusser, Man as a subject or project... Srov.: „It is no coincidence that computer screens help us to have this vision: they are themselves products of the new existential attitude that is emerging. Computers are among the tools by which we begin to assume ourselves as projects. [...] What we now begin to feel is that there are inumerous virtualities around us and within us, that there is no difference between around and within, and those virtualities are opportunities for us to become concrete according to specific projects."

31 Tamtéž.

32 Viz V. Flusser, Vom Subjekt zum Projekt..., s. 40. 
absurdnu ${ }^{33}$ a nikoliv otevřít se skrze dialogické vztahování centrálnímu „Ty“ opředeného tajemstvím jako u Martina Bubera.

Je potřeba upozornit, že Flusserova kritika subjekt-objektového přístupu ke světu, v níž můžeme najít analogie k Buberovu popisu vztahu „Já-Ono“ jednak čerpá i z dalších podnětů, které Flusser sám zmiňuje, a jednak není ve Flusserově podání něčím zcela inovativním. Flusser pro vlastní účely přetváří myšlenkové tendence, které jsou pro reflexi vědy ve dvacátém století typické. Jedním z podstatných zdrojů těchto Flusserových úvah je pojetí intencionality u Edmunda Husserla. Flusser zmiňuje jako další podklad této své úvahy kvantovou mechaniku a Heisenbergův princip neurčitosti a myšlenky, že lidské vnímání vkládá do skutečnosti pouze ty modely, jež je samo schopno pojmout. ${ }^{34}$ Je třeba zmínit i to, že Flusser připisuje předmětné uvažování tradici západního myšlení jako celku napříč celými jejími dějinami. A ačkoliv se i antická filosofie pokoušela učinit z bytí „předmět“ zkoumání, pojmy „subjekt“ a „objekt" se ve skutečnosti v západní filozofii a vědě začaly usidlovat až od renesance a zejména pak v novověké filosofii a vědě.

Posun kontextu mezi Buberovou relací „Já-Ono“ a Flusserovým požadavkem na překonání subjekt-objektové dichotomie souvisí také s pozicí Flusserovy koncepce dialogu v rámci celé jeho komunikační teorie. I zde narazíme na jasné ozvuky Buberovy filozofie dialogu, kterou však Flusser rovněž posunul do jiného rámce. Zatímco u Bubera je řeč zpơsobem, jak se v aktu rozmluvy setkat s bytím prostřednictvím osoby druhého člověka, pro Flussera je lidská komunikace umělým procesem. Spočívá podle něj na symbolech, které člověk uspořádal do kódů. Člověk si už podle Flussera umělý charakter lidské komunikace neuvědomuje. Když se naučíme nějaký kód, máme tendenci zapomenout, že je umělý. Smysl lidské komunikace vymezuje Flusser v podstatě negativně v existenciálním smyslu.

Lidská komunikace je prostředkem zaměřeným na to, abychom zapomněli na brutální nesmyslnost života odsouzeného na smrt. Od „přírody“ je člověk osamělým zviřretem, protože ví, že zemře a že v hodině smrti neplatí žádné nijaké jakkoliv uspořádané společenství: Každý musí umřít sám pro sebe. A potenciálně je každá hodina hodinou smrti. Samozřejmě, s takovým vědomím základní osamělosti a nesmyslnosti se nedá žít. Lidská komunikace nás opřádá závojem kodifikovaného světa, závojem utkaným z umění a vědy, filozofie a náboženství a spřádá ho čím

33 Viz V. Flusser, Von der Selbstlosigkeit..., s. 5.

34 Viz V. Flusser, Vom Subjekt zum Projekt..., s. 35. 
dál hustěji, abychom zapomněli na vlastní osamělost a svoji smrt a i na smrt těch, které milujeme. Shrnuto, člověk komunikuje s jinými, je „politickým zvířetem“ ne proto, že je společenským zviřretem, ale proto, že je osamělým zviŕretem neschopným žít v osamělosti. ${ }^{35}$

Flusserova teorie komunikace se zaobírá právě tímto umělým tkanivem, které je určené k tomu, abychom na onu osamělost zapomněli. ${ }^{36}$ Komunikace usiluje o překonání lidské osamělosti podle Flussera tím, že se snaží zřídit kodifikovaný svět, sestavený z uspořádaných symbolů, v kterém se soustředí získané informace. V odpovědi na otázku, jak lidé vytvářejí a uchovávají informace, Flusser zavádí rozdíl mezi komunikačními formami - diskursem a dialogem. ${ }^{37}$

Dialogická forma komunikace spočívá v tom, že si lidé vyměňují rozmanité, už existující informace v naději, že se z této výměny syntetizuje nová informace. Dialog je tedy metoda, díky které se informace, které jsou uložené ve dvou či více pamětech, vymění a na základě toho vedou k nové syntetizované informaci. ${ }^{38}$ Úkolem diskurzivního typu komunikace je naopak hotové informace uchovávat a předávat dál, a nikoliv vytvářet nové. Obě formy komunikace jsou podstatné. V diskurzu jsou distribuovány informace, které předtím byly rozpracovány v dialogu a v dialogu jsou vyměňovány informace, které předtím byly díky diskurzu uchovávány v paměti. ${ }^{39}$ Flusser vytváří různé typologie diskurzů a dialogů a také typologie společností, podle toho, v jakém poměru se k sobě diskurzy a dialogy v daném společenství nacházejí.

35 Vilém Flusser, Komunikológia, přel. Alma Münzová, Bratislava: Mediálny inštitut 2002, s. 9-10. Srov.: „Ludská komunikácia je fortiel'om zameraným na to, aby sme zabudli na brutálnu nezmyselnosť života odsúdeného na smrṫ. Od ,prírody“ je človek osamelým zvieratom, lebo vie, že zomrie, a že v hodine smrti neplatí nijaké akokolvek uspôsobené spoločenstvo: Každý musí umriet sám pre seba. A potenciálne je každá hodina hodinou smrti. Samozrejme, s takýmto vedomím základnej osamelosti a nezmyselnosti sa nedá žit. L'udská komunikácia nás opriada závojom kodifikovaného sveta, závojom utkaným z umenia a vedy, filozofie a náboženstva a spriada ho čoraz hustejšie, aby sme zabudli na vlastnú osamelost̉ a svoju smrt’ a aj na smrt’ tých, ktorých milujeme. Slovom, človek komunikuje s inými, je ,politickým zvieratom‘, nie preto, lebo je spoločenským zvieratom, ale preto, lebo je osamelým zvieratom, neschopným žit v osamelosti.“

36 Viz tamtéž, s. 10.

37 Viz tamtéž, s. 13.

38 Viz Vilém Flusser, Kommunikologie weiter denken. Bochumer Vorlesungen, Frankfurt am Main: Fischer Taschenbuch Verlag 2009, s. 38.

39 Viz tamtéž, s. 39. 
V „ideální společnosti“ jsou diskurzy a dialogy v rovnováze. Dialogy krmí diskurzy a diskurzy provokují dialogy. Flusser však neuvádí žádný konkrétní případ, kdy by podle něj v dějinách k takové rovnováze docházelo. Druhým typem společnosti je společnost, kde převažují dialogy. Jako př́iklad zmiňuje Flusser dobu osvícenství, kdy prý existovalo velké množství dialogických kroužků, které vytvářejí stále narůstající množství informací (například vědeckých, politických či uměleckých). Tyto elitářské kroužky však nedisponují kanály, které by tyto informace diskurzivně předávaly dál. Takové společnosti hrozí rozpad na informovanou elitu a neinformovanou masu. Třetím typem je diskurzivní společnost. Příkladem je pro Flussera společnost pozdního středověku, kdy podle něj společnost ovládaly centrálně vyzařované diskurzy církve. Protože však chybí dialogy, hrozí vyschnutí zdrojů informací. ${ }^{40}$

Komunikační krize moderní doby podle Flussera spočívá ve dvou aspektech. Za prvé převládají také v dnešní společnosti centrálně, čili jednosměrně vedené diskurzy. Zatímco povaha diskurzů pozdního středověku byla autoritativní, povaha dnešní diskurzivní převahy je automatická. V současné době jsou to podle Flussera aparáty, které programují diskurzy. ${ }^{41}$ Flusser má na mysli masmédia. Druhým kořenem současné krize je podle Flussera fakt, že lidé neprohlédli zásadní proměnu kódů, kterým v současné epoše dochází - ústup lineárních kódů namísto kódů technických obrazů. ${ }^{42}$ Neprohlédli možnosti, které se skrývají v aparátech, jež vytvářejí technické obrazy, i v těch ostatních, a pouze tupě a mechanicky naplňují program, který je v možnostech aparátu obsažen. Flusser upozorňuje, že je možné současné diskurzivní schéma propojení technických obrazů přebudovat na dialogické. Pro techniku, která by to dokázala, zavádí Flusser termín telematika, neologismus, který vznikl spojením slov „telekomunikace“ a „informatika“.43

Tretky telematiky, všechny ty videohry, videofilmy, videodisky a kazety fungují v současnosti jako podpora vysílačů, které je programují. Proto je u nich pocit prázdna oprávněný. Fungují tak však nikoliv proto, že to odpovídá jejich technickému druhu výstavby, nýbrž proto, že jejich uživatelé jsou naprogramováni používat je tak a ne jinak. Jejich způsob výstavby by naopak odpovídal pravému dialogickému fungování. Uživatelé těchto tretek jsou naprogramováni na rozptylování se.

40 Viz Vilém Flusser, Do universa technických obrazů, přel. Jiří Fiala, Praha: OSVU 2001, s. 80.

41 Viz tamtéž.

42 Viz V. Flusser, Komunikológia..., s. 156-157.

43 V. Flusser, Do universa technických obrazů..., s. 76. 
[...] [K] této změně technických obrazů na dialogické fungování musí dojít brzy, nebot jinak bude pozdě. Telematická zařízení ukazují, že k tomu může dojít brzy, možná dokonce hned. Současné hloupé pohrávání si s těmito zařízeními však ukazuje také, že je možné propást žádoucí okamžik. Tak jak jsou nyní telematické tretky používány, vytvářejí totiž prázdné řeči a žvanění, záplavu banálních technických obrazů, které jsou s to definitivně zalepit všechny mezery mezi osamocenými a rozptýlenými, tlačítka stiskávajícími masovými lidmi. Brzy už nebude nic, o čem bychom si mohli vzájemně povídat. Proto je ted' ta chvíle promluvit o tom. ${ }^{44}$

Ačkoliv Flusser shledává současnou společnost v komunikační krizi, vidí v základech jejích dominantních komunikačních technologií také prostředky pro její překonání. A snaží se popsat parametry svého utopického ideálu telematické společnosti. Je to informační společnost, která by si byla vědoma, že vytváření informací je její bytostnou funkcí, a mohla by tudíž toto vytváření informací metodicky pohánět dopředu, a byla by tudíž první fakticky svobodnou společností. Telematizovaná společnost by ve Flusserově pojetí vytvořila sít dialogů, kterou by bylo možné pokládat za vnitřní dialog celé společnosti. Celá společnost by se stala tvořivou. Flusser popisuje telematickou společnost jako jeden velký supermozek, který je složený z individuálních mozků. Zde opět Flusser zmiňuje svoji myšlenku, že ,já“ je pouze uzlovým bodem této dialogické sítě. $\mathrm{V}$ této nové společenské struktuře už nebudou existovat vysílací centra, ale každý uzlový bod sítě bude současně přijímat i vysílat. ${ }^{45}$

Telematická společnost podle Flussera vtiskne pojmu „tvoření“ nový význam. Nepotřebujeme už prý „Autory“ ani „Velké mistry“, kteří v nové společnosti ani nemohou fungovat. Mohou naopak vznikat intersubjektivní dialogy, které jsou prý nesrovnatelně kreativnější, než mohly být dialogy „velkých mužư “.

Dialogy typu laboratoř nebo pracovní tým, v nichž se lidské a umělé paměti propojují, aby syntetizovaly informace. Již dnes vytvářejí tyto dialogy takové množství nových a zčásti převratných informací, o němž nemohli velcí mistři minulosti ani snít. A telematická společnost bude jediným obrovským dialogem tohoto typu, na němž se budou moci podílet teoreticky všichni lidé. ${ }^{46}$

44 Tamtéż, s. 81-83.

45 Viz tamtéž, s. 84-89.

46 Tamtéż, s. 96. 
Informace telematické společnosti už ale nebudou díla nebo objekty, ale nesubstanční zprávy, informace. Budoucí člověk bude při tomto vytváření informací, tvưrčím procesu, strháván do sebezapomnění, protože bude vstupovat do hry s ostatními prostřednictvím aparátů. Nebude to ale podle Flussera znamenat ztrátu sebe sama, naopak půjde o konkretizaci sebe sama prostřednictvím hry. ${ }^{47}$

Budoucí hrající člověk se nalezne prostřednictvím tvưrčí hry v jiném člověku, v rozhovoru, v němž budou všichni všem říkat „ty“, v této tvůrčí hře vzájemného uznání jiných. Právě to zde míníme „hraním“, „tvořením“, „telematikou“. ${ }^{4}$

Důležitý rozdíl mezi pojetím dialogu u Bubera a Flussera tkví podle Olivera Bidla v tom, že Buber zůstává kritický k dialogu zprostředkovanému skrze média. A za jedinou autentickou formu považuje dialog osob tváří v tvář. Flusser posouvá Buberův koncept dialogu k celé telematické společnosti a novým komunikačním podmínkám. ${ }^{49}$ Společným prvkem mezi oběma autory je naopak skutečnost, že se v základu oba zabývají spíše formou a podmínkami autentického dialogu a méně se zaměřují na jeho obsah. Flusser mluví o syntetizování nových informací prostřednictvím dialogu, aniž by oceňoval jejich kvalitu, a Buber zase klade váhu na vznik dimenze „mezi“, intersubjektivitu, která představuje konstitutivní prvek dialogu. ${ }^{50,51}$

47 Viz tamtéz̆, s. 100.

48 Tamtéz.

49 Viz O. Bidlo, Martin Buber..., s. 207 a 208.

50 Viz tamtéž, s. 231.

51 V souvislosti s Flusserovou utopickou vizí takzvané telematické společnosti se nabízí otázka, zda je Flusserova koncepce v určitém vztahu k teorii komunikativního jednání, kterou formuloval převážně v osmdesátých letech 20. století německý filozof a sociolog Jürgen Habermas. Navzdory Flusserovu vágnímu přístupu k citačním systémům najdeme v jeho textech množství odkazů na jiné autory. Habermas mezi nimi není. Také Habermas ve svém opusu vychází z prací mnoha další sociologů a filozofů, ale Flussera, který nikdy nepatřil k hlavnímu proudu německých akademiků a teoretiků, neuvádí. Přesto mezi oběma koncepcemi najdeme společné momenty. Oba autoři kritickým způsobem vycházejí z některých východisek Frankfurtské školy (Habermas je dokonce řazen k její další generaci). Habermasova teorie komunikativního jednání má ambici být základem veškeré sociální vědy, za situace kdy dochází ke stále intenzivnějš́ patologizaci a kolonizaci žitého světa kvưli jeho střetávání se systémem, v němž dominuje funkcionální rozum. Viz Jürgen Habermas, The Theory of Communicative Action, Vol. 1, trans. by Thomas McCarthy, Boston: Beacon Press 1984, s. xl. Podle Detlefa Horstera se Habermas domnívá, že člověk a společnost jsou dnes nejvíce ohroženi pronikáním byrokratických instancí do sociálních vztahů. Teorie komunikativního jednání má být nástrojem, který umožní vyvázání společnosti z ryze účelového 
U Bubera, který se soustředí na moment setkání s druhým, prostřednictvím kterého se setkáváme s oním centrálním Druhým, a to v aktu oslovování, jež má jasný mystický či religiózní rozměr, jež lze spíše zakusit, než o něm něco vypovědět, se zřejmě nejedná o závažný problém. V případě Flusserovy koncepce posunuté ke strategiím komunikačních technologií už jisté sporné momenty vznikají. Flusser komunikační teorii a teorii technických obrazů, jež jsou převládající zobrazující formou v posthistorické době, a jež prostřednictvím aparátů proměňují strukturu lidské existence včetně lidského vědomí, začal promýšlet od sedmdesátých let 20. století, jasné formulace doznala až v průběhu let osmdesátých. Tedy v době, kdy se již rozvijejí hypertexty a fenomén internetu, ale celkově ještě převládají jednosměrná média a vysílače jako televize, kino, rozhlas či tištěný periodický tisk. Právě první pokusy s internetem zřejmě Flussera inspirovaly $\mathrm{k}$ utopické vizi jednotné demokratické sítě, kde mohou být všichni v dialogu prakticky se všemi, a z níž budou prostřednictvím hravé formy intersubjektivního dialogu vznikat synteticky nové informace. Problém nastává v tom, že Flusser do své úvahy nezahrnul žádnou kvalitativní veličinu, na základě které by bylo možné rozlišit, kdy se jedná o redundanci a komunikační balast a kdy o nově synteticky vzniklou informaci. Různí lidé, různé uzly velkého intersubjektivního dialogu, řečeno Flusserovými slovy, by zřejmě nebyli schopní dojít k jednotnému stanovisku.

V tomto bodě se Flusserova telematická vize zdá být naivní či překonaná. Fenomén internetu od přelomu tisíciletí zcela proměnil veřejný ko-

a funkcionálního uvažování ve prospěch morálně racionálního rozumu. Vědění životního světa je podle Habermase obsaženo v jazyce, protože životní svět podle něj sestává z individuálních dovedností, intuitivního vědění, jak se vypořádat s určitými situacemi, sociálně nacvičených praktik i z triviálních vědomých přesvědčení, jež právě jazyk zprostředkovává. Viz Detlef Horster, Jürgen Habermas, přel. Eduard Urbánek, Praha: Svoboda 1995, s. 50-51. Byrokratizace a funkcionalizace uvažování a komunikace a snaha o návrat k autenticitě životního světa u Habermase je jistou paralelou k Flusserově tezi o převaze jednosměrné diskurzivní komunikace na úkor dialogů. Habermasův projekt je však daleko více politický a praktický a Flusserův spíše utopicko-vizionářský. Zatímco Habermas ve svém díle nabízí konkrétní př́klady analýzy řečových aktů pro potřeby současné společnosti poháněné kapitalistickým hospodářstvím, které hodnotí kriticky stejně jako ostatní představitelé Frankfurtské školy, Flusser vykresluje časově neukotvený obrázek o ideální telematické společnosti, ve které probíhá ideální komunikace za pomoci nových technologií. Obsah komunikace ponechává stranou. Nuanci najdeme u obou autorů také v otázce, co je hybnou silou stávající technizace lidské komunikace. Zatímco pro Flussera je to spíše technický pokrok jako takový, Habermas ji explicitněji přičítá spíše kapitalistickému hospodářství a rozmachu kapitálu. A je otázka, jestli lze tyto jevy jednoznačně ztotožňovat. Viz Jürgen Habermas, The Theory of Communicative Action, Vol. 2, trans. by Thomas McCarthy, Boston: Beacon Press 1989, s. 396. 
munikační prostor, jednosměrné kanály komunikace byly do velké míry nahrazeny těmi sítovými, tuto situaci ještě prohlubuje rozmach sociálních sítí. Rozhodnout, zda tato proměna vede ke svobodné telematické společnosti, nebo se pouze prohloubila masovost a mechaničnost lidských gest, opět řečeno Flusserovými slovy, jež pouze kopírují gesta, jež jim vnucují technologie, nelze rozhodnout, bez toho, abychom se zaměřili na kvalitu sdílených informací, což je velmi nejednoznačná veličina.

Jak bylo nastíněno výše, doznala Flusserova koncepce dialogu značného posunu oproti původní Buberově inspiraci. Z centra svých úvah o komunikaci totiž Flusser religiózní aspekt vypouští. Přesto je potřeba položit si otázku, zda v pozadí jeho úvah není jistý moment religiozity imanentně přítomen, a to v podobě židovské tradice. Flusser totiž vlastní židovství hojně reflektuje.

Flusser nebyl ortodoxním Židem praktikujícím rituály víry. V Bezednu popisuje, že již v mládí v rodné Praze pocitoval prázdný formalismus obřadů, jež přežily odumírající tradici. Cítil k nim sice estetickou přitažlivost, ale zároveň věděl, že tato přitažlivost zastírá vše, co je na fenoménu náboženství důležité.

K židovským textům neměl prakticky žádný př́stup, jednak proto, že tyto texty byly napsány stylem, který mu byl naprosto cizí. Pražští ortodoxní Židé, kteří většinou pocházeli z Haliče, mu byli daleko cizejší než pražští katolíci. V podstatě vůbec neměl právo, aby se v náboženském smyslu považoval za Žida. ${ }^{52}$

Přesto mu prý židovství uzavíralo cestu také ke křestanství. Protože osvětlovalo jeho dogmatickou stránku, která oslabovala jeho existenciální poselství, a také prý Flusser nemohl překlenout historický myšlenkový rozpor mezi křestanskou láskou a knězi vyzývajícími k pogromům. ${ }^{53}$

Flusser ale přiznává, že je nemožné, aby některé stránky židovského stylu uvažování vůbec kdy překonal. Mimo jiné proto, že celé západní myšlení stojí podle něj na dvou základech - řeckém a židovském, které koexistují a působí v myšlení každého západního člověka. Zatímco Řekové podle něj žili a mysleli „esenciálně“, Židé žijí a myslí „existenciálně“. Původní židovství totiž Flusser interpretuje jako sumu modelů chování, které mají absurdnímu životu propůjčit význam. Flusserovo pojetí židovství

52 Viz V. Flusser, Bezedno..., s. 17.

53 Viz tamtéz. 
je tedy stejné jako jeho pojetí komunikace. Celé židovství je podle něj výzva absurdnu. „To je jeho klima. Dokládá to nejen Hiob, ale i Kafka.“54 Co přesně tím Flusser myslí, rozvádí na popisu židovského ritu a líčení svého přítele Romyho Finka, který byl anglickým ortodoxním Židem a se kterým se Flusser seznámil v Brazílii.

Z nepřeberného množství poučení, která mi Romy zprostředkoval, uvedu zde jen dva body, nebot měly mimořádný vliv na můj budoucí život: rituál a úctu k bližnímu. [...] Ale pozorovat ho bylo lepší metodou, jak vniknout do ducha židovství: vidět, že nesčetné příkazy a zákazy nejsou omezení, nýbrž existenciálním osvobozením k smysluplnému, protože posvěcenému životu. [...] To je tedy sabat: cítit konkrétní smysl života nad sebou i v sobě, a to v soužití s bližními a v otevření se Onomu zcela jinému. [...] Zkrátka smysl života se odhaluje ve slavnostním soužití, ale slavnostní soužití se řídí pravidly, která se sama o sobě zdají být zcela beze smyslu. To je podstatou židovských ritů. [...] Druhý aspekt židovství, který mi Romy svým životem předvedl, byla úcta $\mathrm{k}$ bližnímu. Na začátku našeho přátelství mě jeho chování poněkud odpuzovalo, protože byl na můj vkus příliš zdvořilý a přímo překypoval přehnanou chválou všech ostatních. To mě odrazovalo, poněvadž jsem nemohl uvěřit, že je to míněno doopravdy. Později jsem tento postoj začal chápat, a ještě později, když jsme s Romym jednou diskutovali o talmudu, jsem pochopil souvislosti. Pro židovství - tak on vykládal talmud - existuje jeden jediný neodčinitelný hřích: urážka bližního. Všechny ostatní hříchy se dají odčinit, tento však nikdy, nebot̉ zasahuje neoddělitelnou podstatu druhého. A bližní je jediný způsob, jak konkrétně zažívám Boha. Bůh je v bližním. Jestliže urazím bližního, urazil jsem Boha. [...] Zda v Boha věřím či nevěřím, je naprosto lhostejné, a jak v něj věřím, je možná ještě lhostejnější: ale sloužím mu, když ctím svého bližního. ${ }^{55}$

Flusser doplňuje, že se mu tím přibližila židovská teorie, praxe nikoliv. Přesto v jiné své eseji přiznává, že člověk myšlenkově je a zůstává židem, at proti tomu činí cokoliv či svou identitu vědomě či nevědomě zapírá. ${ }^{56}$ Dokazuje to sám na sobě. A dokonce tvrdí, že talmudické myšlení se odráží přímo

54 Viz Vilém Flusser, Jude sein (2) - kultureller Aspekt in Vilém Flusser, Edith Flusser (ed.) - Stefan Bollmann (ed.), Jude sein: Essays, Briefe, Fiktionen, Mannheim: Bollmann 1995, s. 67-71. Srov.: „Das ist sein Klima. Nicht nur Hiob, auch Kafka bezeugt es.“

55 V. Flusser, Bezedno..., s. 139-143.

56 Vilém Flusser, Judenstaat '91, in V. Flusser, E. Flusser (ed.) - S. Bollmann (ed.) Jude sein..., s. 123. 
v jeho argumentacích týkajících se filozofie a vědy, a to navzdory tomu, že Flusser talmud původně nijak detailně nestudoval. $\mathrm{S}$ překvapením prý také zjistil, že na tento fenomén narazil také u jiných židovských myslitelů, kteří nauku talmudu znali stejně málo jako on. ${ }^{57}$

Tuto svoji tendenci k talmudizování jsem si uvědomil poměrně pozdě, totiž když jsem se začal v průběhu mých studií zajímat o klasickou židovskou literaturu. Proto moje překvapení: Zpětně jsem rozpoznal svou vlastní techniku myšlení v literatuře, která mi byla cizí. Tematika klasických židovských myslitelů neměla s mou vlastní mnoho společného. Četl jsem Midraše, jako jsem četl Popul Vuh nebo Tibetskou knihu mrtvých. A přece jsem nemohl popřít, že „logika“ Midraší je mou vlastní logikou, ačkoliv jsem se domníval, že jsem si přece osvojil jinou logiku, totiž tu řeckou. Toto překvapující odhalení je trapné. Je trapné, muset zjistit, že technika, kterou člověk během myšlení používá, nebyla vědomě vypracována, ale pochází z programu, který si člověk nevybral a kterého si ani nebyl vědom. ${ }^{58}$

Tato citace dobře ukazuje, jakým zpo̊sobem se židovský styl myšlení ve Flusserově vlastní práci promítá, přestože židovská víra jako taková není pro Flussera tématem, ani východiskem jeho úvah. Důraz na řeč a komunikaci, dialog s druhým, snaha o překonání předmětného uvažování a pocitu absurdního osamění jsou témata, která Flusser nachází jako motivy židovského uvažování. Nezávisle na něm je však sám také tematizuje, jak se ukázalo v předchozích odstavcích.

Pokud Flusser tematizuje židovský styl myšlení, činí tak v kontextu úvah o jazyku a komunikaci. Jestliže Flusser sám přiznává, že tento typ uvažování pronikl do jeho filozofie vlastně neuvědoměle a automaticky, je otázka, zda

57 Viz Vilém Flusser, Pilpul (I), in V. Flusser, E. Flusser (ed.) - S. Bollmann (ed.) Jude sein..., s. 138.

58 Tamtéž. Srov.: „Diese meine Tendenz zum Talmudisieren stelle ich relativ spät fest, nämlich als ich beginne, mich im Laufe meiner Studien für die klassische jüdische Literatur zu interessieren. Daher meine Überraschung: Ich erkenne in einer mir fremden Literatur meine eigene Denktechnik wieder. Die Thematik der klassischen jüdischen Denker hat mit meiner eigenen so gut wie nichts zu schaffen. Ich lese die Midraschim, wie ich den Popol Vuh oder das Tibetanische Totenbuch lese. Und doch kann ich nicht leugnen, daß die ,Logik' der Midraschim meine eigene ist, obwohl ich doch eine andere Logik, nämlich die griechische, glaube erworben zu haben. Diese überraschende Entdeckung ist peinlich. Es ist peinlich, feststellen zu müssen, daß die Technik, die man beim Denken anwendet, nicht bewußt ausgearbeitet wurde, sondern einem Programm entstammt, das man nicht gewählt hat und dessen man sich nicht einmal bewußt war." 
ozvuky židovské tradice obecně nemůžeme najít i v dalších sférách Flusserovy filozofické práce. A to například v jeho teorii obrazu.

Ve starozákonní podobě desatera přikázání v Mojžíšových knihách Starého zákona jedno z přikázání zakazuje vytvářet vizuální zobrazení Boha. („Nezobrazíš si Boha zpodobením ničeho, co je nahoře na nebi, dole na zemi nebo ve vodách pod zemí. Nebudeš se ničemu takovému klanět, ani tomu sloužit.") Dané přikázání má předcházet takzvané modloslužbě, idolatrii, službě obrazům, tedy tomu, že člověk svou náboženskou pozornost zaměří na zástupnou formu a nikoliv na pravou skutečnost.

Stejnou nedůvěru k zobrazování Boha vyjadřuje také Buber ve své pražské přednášce z roku 1937. Nejde podle něj pouze o malované obrazy a sochy, ale v podstatě o jakékoliv naše domněnky, obrazotvornost jakožto celek. Nepopírá, že touha člověka nějakým obrazem uchopit Boha a přiblížit se mu tu byla vždy, tyto pokusy ale vždy musí být po nějaké době zavrženy jako nedostatečné. ${ }^{59}$

Flusser uvažuje o obrazech opět mimo náboženský rámec. Jeho základním předpokladem, týkajícím se obrazů, ostatně jakožto všech symbolů a kódů, je tvrzení, že nejsou reprezentacemi světa, ale prostředky mezi člověkem a světem, které nám pohled na skutečnost spíše zatemňují. Podle Flussera je nesprávné, vidíme-li v obrazech „zmrazené události“. Obrazy spíše převádějí události do výjevů. Svět člověku není přístupný bezprostředně, proto mu jej podle Flussera mají zprostředkovat obrazy. Kdykoliv to činí, staví se však mezi člověka a svět. ${ }^{60}$

Mají být mapami, a stávají se španělskými stěnami: Místo, aby svět představovaly, zakrývají ho, až člověk nakonec začíná žít ve funkci obrazů, které sám vytvořil. Přestává obrazy dešifrovat a místo toho, je nedešifrované promítá do světa „tam venku“, čímž se mu svět stává souhrnem obrazů - kontextem výjevů, věcnou konfigurací. ${ }^{61}$

Pro toto obrácení funkce používá Flusser termín idolatrie (modloslužba) - lidé zaměňují obrazy za skutečnost. V současné době se všudypř́ítomné technické obrazy podle Flussera chystají lidskou „skutečnost“ převrátit a pře-

59 Viz M. Buber, Předsudky mládeže..., s. 10.

60 Viz Vilém Flusser, Za filosofi fotografie, přel. Božená Koseková - Josef Kosek, Praha: Hynek 1994, s. 9.

61 Tamtéž. 
strukturovat v globální obrazový scénář. Člověk podle Flussera zapomíná, že sám obrazy vytvořil, aby se orientoval ve světě. ${ }^{62}$ Flusser to chápe jako nežádoucí stav, jelikož zaměňujeme neautentické za autentické. Zcela stejným směrem plyne i Buberova výše nastíněná úvaha i př́íkaz desatera. ${ }^{63}$ $\mathrm{V}$ př́ípadě teorie obrazu jde již o čistý interpretační krok této statě, protože Flusser ji sám v kontextu židovství nerozebírá. Vzhledem k výše načrtnutým paralelám mezi židovským myšlením a Flusserovou komunikační

62 Viz tamtéž, s. 10.

63 Na tomto místě se opět objevuje otázka, zda ve Flusserově koncepci technického obrazu nemůžeme narazit na podobnost s koncepcí simulaker a simulace Jeana Baudrillarda. Baudrillard hovoří o třech řádech simulaker. Za prvé jsou to naturalistická simulakra, která jsou založena na obraze, na vztahu reference. Za druhé jsou to simulakra, která jsou založena na produktivitě, energii a celém systému produkce, posledním řádem jsou simulakra simulace, která jsou založena na informacích, jejich výsledkem jsou modely, kybernetická hra a hyperrealita. Obdobně jako Flusser vidí Baudrillard v průběhu dějin vývoj od jednoho dominantního typu komunikace ke druhému. Viz Jean Baudrillard, Simulacra and Simulation, trans. by Sheila Faria Glaser, Michigan: Ann Arbor 1994, s. 121. Titul „Simulakra a simulace“ vyšel poprvé ve francouzském originálu v roce 1981, tedy dva roky před prvním vydáním Flusserovy eseje Za filozofi fotografie. Baudrillard ve svém souboru esejí tvrdí, že pro současnou masmediální éru jsou typická simulakra z řádu simulace, která ruší jakoukoliv možnost vztahu mezi obrazem a tím, co má být reprezentováno, protože je mezi nimi zrušena přirozená distinkce. Dnešní modely z řádu hyperreality již totiž podle Baudrillarda neumožňují určit rozdíl mezi realitou a jejím modelem. Viz tamtéž, s. 6. Podle Andrease Ströhla je Flusserova diskrepance mezi realitou a jejím obrazem radikálnější než ta Baudrillardova. Podle Ströhla totiž Baudrillard aspekt reality zachovává, i když ji již nejsme schopni rozlišit od jejích modelů, s nimiž se směšuje, zatímco Flusser podle něj popírá možnost vůbec hovořit o instanci reality jako takové, popírá vůbec jakoukoliv existenci věcí o sobě. Rozhodující prý už nejsou ontologické rozdíly. Viz A. Ströhl. Vilém Flusser (1920-1991)..., s. 70. Např́k lad z výše uvedené citace z eseje Za filozofii fotografie však vysvítá, že i Flusser jistý řád reality, který je zastíněn obrazy, předpokládá. S Baudrillardem tedy mají spíše společnou představu, že o obrazech již dnes nemůžeme hovořit jako o něčem, co by nám realitu přibližovalo, ale jako o něčem, co ji nahrazuje sebou samým. Rozdíl je v tom, co z dané koncepce oba autoři vyvozují. Zatímco Flusserův pesimistický popis ústí v jeho optimistickou vizi telematické společnosti a možnosti vymanit se z aparátního fungování, pokud se obrazy a funkce aparátů naučíme dešifrovat, Baudrillardův pesimistický popis ústí v radikální nihilismus. Bojovat proti statu quo je podle něj sentimentální. „Protože tomuto aktivními nihilismu radikality oponuje systém svým vlastním, nihilismem neutralizace. Systém sám o sobě je také nihilistický v tom smyslu, že má sílu slít vše, včetně toho, co jej popírá, do indiference.“ J. Baudrillard, Simulacra and Simulation..., s. 163. Srov. „Because to this active nihilism of radicality, the system opposes its own, the nihilism of neutralization. The system is itself also nihilistic, in the sense that it has the power to pour everything, including what denies it, into indifference. "A v př́padě zobrazování božského jde Baudrillardova nedůvěra $\mathrm{k}$ obrazům ještě dále. Ikonoklastické hnutí totiž podle něj usilovalo o odstranění obrazů božství ne proto, že by zástupné mohlo být zaměňováno za reálné, ale proto, že by mohlo dojít k odhalení, že obrazy boží ničemu neodpovídají, že v hloubi skutečnosti žádný Bůh neexistuje, pouze jeho simulakrum. Viz tamtéž, s. 4. 
teorií a koncepcí dialogu, nemusí být však tato souvislost náhodná nebo interpretačně vykonstruovaná.

V průběhu této statě jsme ukázali, že myšlení Martina Bubera i židovská filozofie obecně doznaly ve Flusserově podání značného posunu daleko za původní rámec a intence. I tak ve Flusserových textech zůstávají jak Buber, tak židovská tradice velmi výrazně př́ítomné. A to mimo jiné ve Flusserově existenciálním rozpoložení, které přikládá i svým čistě teoretickým projektům, protože jejich hlavním smyslem koneckonců pro Flussera je, předložit je k debatě druhému.

\section{Mgr. Klára Židková}

Katedra filozofie, Filozofická fakulta, Masarykova univerzita

Arna Nováka 1, 60200 Brno, Česká republika

264011@mail.muni.cz 